\title{
PENGARUH PENGAWETAN KULIT IKAN BUNTAL (Arothon reticularis) TERHADAP SUHU KERUT DITINJAU MELALUI ANALISIS DIFFERENTIAL SCANNING CALORIMETER (DSC)
}

\section{THE EFFECT OF PRESERVATION METHODS ON SHRINKAGE TEMPERATURE OF PUFFER FISH SKIN USING DIFFERENTIAL SCANNING CALORIMETER (DSC) ANALYSIS}

\author{
RLM. Satrio Ari Wibowo*, Muh. Wahyu Sya'bani \\ Politeknik ATK Yogyakarta, Jln Ring Road Selatan, Panggungharjo, Sewon, Bantul 55188, Indonesia \\ *Penulis korespondensi. Telp./Fax.: +62 274383727 \\ E-mail: alexius_wibowo@yahoo.com
}

Diterima: 30 Agustus 2015 Direvisi: 10 Oktober $2015 \quad$ Disetujui: 23 November 2015

\begin{abstract}
The aim of this study was to determine the effect of the skin preservation type against shrinkage temperature of leather. The material used in this study was the skin of pufferfish (Arothon reticularis) that have been preserved by salting, formaldehyde and pickling and also raw skin as a reference. The method used to measure the shrinkage temperature was thermal analysis using differential scanning calorimeter (DSC) that operated from $4^{\circ} \mathrm{C}$ up to $440^{\circ} \mathrm{C}$ with nitrogen stream. DSC measurement results showed that shrinkage temperature of puffer fish preserved with formaldehyde was higher than salting and pickling, which is $63.64^{\circ} \mathrm{C} ; 47.95^{\circ} \mathrm{C} ; 57.37^{\circ} \mathrm{C}$ respectively. The advantage of using formaldehyde compared to others preservation technique was not only can protect the skin from damage by microorganisms, but also can create a bond with the collagen.
\end{abstract}

Keyword: Puffer fish, differential scanning calorimeter, skin preservation.

\begin{abstract}
ABSTRAK
Penelitian ini bertujuan untuk mengetahui pengaruh jenis pengawetan kulit terhadap indikator penting kualitas kulit yaitu shrinkage temperature. Material yang digunakan adalah kulit ikan buntal (Arothon reticularis) yang sudah diawetkan dengan penggaraman, formaldehid dan pengasaman serta kulit mentah sebagai blangko. Metode yang digunakan untuk mengukur shrinkage temperature adalah analisis thermal menggunakan differential scanning calorimeter (DSC) yang dioperasikan mulai suhu $4^{\circ} \mathrm{C}$ sampai dengan $440^{\circ} \mathrm{C}$ dengan aliran gas nitrogen. Hasil pengukuran DSC menunjukkan shrinkage temperature kulit ikan buntal awetan formaldehid lebih tinggi dibandingkan awetan penggaraman dan pengasaman, yaitu berturut-turut $63,64{ }^{\circ} \mathrm{C} ; 47,95{ }^{\circ} \mathrm{C} ; 57,37{ }^{\circ} \mathrm{C}$. Kelebihan dari formaldehid selain dapat melindungi kulit dari kerusakan oleh mikroorganisme, juga dapat membuat ikatan dengan kolagen kulit.
\end{abstract}

Kata kunci: Ikan buntal, differential scanning calorimeter, pengawetan kulit.

\section{PENDAHULUAN}

Kulit mentah adalah merupakan bahan baku industri penyamakan kulit. Untuk mendapatkan produk industri penyamakan kulit yang bermutu baik (kulit jadi yang baik), selain dipengaruhi proses penyamakan yang baik, juga dipengaruhi oleh kulit mentah yang bermutu baik pula, atau dengan kata lain berkualitas baik. Seperti halnya dengan kulit-kulit hewan lainnya, kulit dari suatu ikan juga mengandung protein yang jumlahnya $\pm 26,9 \%$. Protein ini sangat mudah sekali diserang oleh bakteri pembusuk. Oleh karena itu kulit mentah baik dalam keadaan basah maupun dalam keadaan kering bila tanpa diawetkan maka akan mudah membusuk bila disimpan lama. Oleh karena itu agar tahan disimpan lama, maka perlu dilakukan usaha pengawetan terhadap kulit mentah segar, karena tujuan dari pengawetan adalah melindungi kulit terhadap serangan bakteri, jamur dan serangga yang menyebabkan terjadinya pembusukan dan 
kerusakan kulit mentah (BBKKP, 1991). Selama ini, limbah kulit ikan belum dimanfaatkan secara optimal dan dibiarkan begitu saja menjadi sampah. Padahal, limbah kulit ikan memiliki potensi yang cukup besar untuk dikembangkan dalam industri kulit. Salah satu sumberdaya hayati perikanannya adalah ikan buntal. Menurut Weber \& de Beaufort (1962), ikan ini tergolong jenis ikan perenang lambat dan memiliki kemampuan mengembung dengan jalan memasukan udara dan air kedalam perutnya. Hidupnya di laut, muara sungai dan perairan tawar.

Penggunaan kulit ikan sebagai bahan baku produk kulit juga bertujuan untuk mengurangi perburuan satwa liar yang masuk dalam konservasi dan digunakan sebagai bahan baku industri kulit. Wibowo et al. (2014) menyatakan kemuluran kulit ikan buntal mentah sebesar $88,94 \%$, kulit ikan buntal garaman sebesar $114,15 \%$, kulit ikan buntal pickle sebesar $96,84 \%$ dan kulit ikan buntal formalin sebesar $84,72 \%$ dari hasil tersebut cukup baik untuk standar produk kulit. Akan tetapi bagaimana dengan analisis termalnya perlu dikaji kembali.

Analisis termal dalam pengertian luas adalah pengukuran sifat kimia fisika bahan sebagai fungsi suhu. Penetapan dengan metode ini dapat memberikan informasi pada kesempurnaan kristal, polimorfisma, titik lebur, sublimasi, transisi kaca, dedrasi, penguapan, pirolisis, interaksi padatpadat dan kemurnian. Analisis termal DSC digunakan untuk mengetahui fase-fase transisi pada polimer. Analisis ini menggunakan dua wadah sampel dan pembanding yang identik dan umumnya terbuat dari alumunium (Martianingsih \& Lukman, 2010). Differential Scanning Calorimeter (DSC) merupakan salah satu alat dari thermal analyzer yang dapat digunakan untuk menentukan kapasitas panas dan entalpi dari suatu bahan (Ginting et al., 2005).

Menurut Nurjannah (2008), prinsip kerja analisis termal DSC didasarkan pada perbedaan suhu antara sampel dan suatu pembanding yang diukur ketika sampel dan pembanding dipanaskan dengan pemanasan yang beragam. Perbedaan suhu antara sampel dan zat pembanding yang lembam (inert) akan teramati apabila terjadi perubahan dalam sampel yang melibatkan panas seperti reaksi kimia, perubahan fase atau perubahan struktur. Jika $\Delta \mathrm{H}(-)$ maka suhu sampel akan lebih rendah daripada suhu pembanding, sedangkan jika $\Delta \mathrm{H}(+)$ maka suhu sampel akan lebih besar daripada suhu zat pembanding. Perubahan kalor setara dengan perubahan entalpi pada tekanan konstan.

Data yang diperoleh dari analisis DSC dapat digunakan untuk mempelajari kalor reaksi, kinetika, kapasitas kalor, transisi fase, kestabilan termal, kemurnian, komposisi sampel, titik kritis, dan diagram fase. Termogram hasil analisis DSC dari suatu bahan polimer akan memberikan informasi titik transisi kaca (Tg), yaitu suhu pada saat polimer berubah dari bersifat kaca menjadi seperti karet, titik kristalisasi $(T \mathrm{c})$, yaitu pada saat polimer berbentuk kristal, titik leleh $(T \mathrm{~m})$, yaitu saat polimer berwujud cairan, dan titik dekomposisi (Td), yaitu saat polimer mulai rusak. Tujuan Penelitian ini adalah untuk mengetahui kondisis termal dari kulit ikan buntal mentah dan tiga macam jenis pengawetan yaitu garaman, pengasaman dan formalin. Analisis DSC digunakan untuk mengetahui perbedaan sifat fisis pada sifat termal kulit ikan buntal Arothon reticularis.

\section{BAHAN DAN METODE Bahan Penelitian}

Materi yang digunakan dalam penelitian adalah 12 lembar kulit ikan buntal yang diambil di daerah Rembang. Dilakukan 3 (tiga) macam metode pengawetan yaitu formalin, pengasaman dan penggaraman.

\section{Peralatan Penelitian}

Peralatan yang digunakan adalah alat utama Differential Scanning Calorimeter (DSC) Perkins Elmer DSC-4000 dengan sampel pan tertutup. DSC dilengkapi dengan chiller supaya dapat memulai pemanasan pada suhu yang lebih rendah dari suhu kamar. Sedangkan peralatan pembantu antara lain neraca analitik digital dan gunting.

\section{Metode Penelitian}

Kulit ikan buntal mentah diambil 4 lembar diawetkan secara garam jenuh yaitu larutan garam jenuh yang telah disiapkan dalam bak perendaman dengan kepekatan $20-24^{\circ} \mathrm{Be} ., 4$ lembar diawetkan dengan $40 \%$ formaldehyde dan 4 lembar diasamkan dengan natrium sulfat $17 \%, 1 \%$ asam formiat dan ditambahkan 3\% asam klorida.

Sampel dipotong kecil-kecil kemudian ditimbang pada neraca analitik digital dengan berat maksimum $30 \mathrm{mg}$. Selanjutnya sampel dimasukan dalam sampel pan dan diklem sampai tertutup rapat. Di dalam DSC sampel pan dipanaskan dari suhu 4 sampai $440{ }^{\circ} \mathrm{C}$ dengan kecepatan pe- 
manasan $5^{\circ} \mathrm{C} /$ menit dan aliran gas nitrogen $30 \mathrm{ml} /$ menit. Stabilitas termal dari kolagen merupakan karakteristik penting untuk meninjau kualitas dari kulit, karena nilainya menunjukkan secara tidak langsung akan destabilisasi struktur dari matriks kulit. Stabilitas termal dari kulit pada umumnya di tunjukkan melalui suhu kerut. Pada tulisan ini, DSC digunakan untuk menentukan suhu kerut dari awetan kulit ikan buntal. Metode pengujian dengan DSC mengikuti standar prosedur alat Perkins Elmer DSC-4000 tanpa pengulangan sampel.

Menurut Kanagaraj et al. (2005) suhu dimana sampel mulai mengkerut didefinisikan sebagai suhu kerut dari kulit. Apabila menggunakan metode DSC maka data onset dari transisi endotermis diambil sebagai suhu kerut (Jeyapalina et al., 2007). Suhu kerut adalah pengukuran dari putusnya ikatan penstabil yang ada di matrik kolagen. Tujuan utama dari pengukuran ini adalah untuk mengetahui apakah sistem pengawetan yang dilakukan memiliki efek pada distabilisasi matrik kolagen.

\section{HASIL DAN PEMBAHASAN Suhu Kerut Kulit Ikan Buntal}

Kurva grafik DSC dari kulit mentah ikan buntal, pengawetan dengan penggaraman, pengawetan dengan formalin dan pengasaman disajikan pada Gambar 1. Bentuk peak yang asimetri pada masing-masing kurva disebabkan perbedaan kestabilan hidrotermal dari populasi kolagen penyusun kulit ikan. Bagian puncak kurva yang berada pada suhu lebih tinggi menunjukan populasi kolagen dengan kestabilan yang lebih baik (Cucos et al., 2014). Jumlah ikatan silang atau cross linkage yang terbentuk menentukan suhu kerut kulit samak aldehid. Semakin banyak jembatan oxymethylene, maka suhu kerut semakin tinggi. Kenaikan suhu kerut sangat signifikan dengan jumlah aldehid yang terikat, sedangkan aldehid terikat tergantung pada $\mathrm{pH}$ cairan penyamakan (Purnomo, 2009).

Besarnya ketahanan kulit terhadap panas (hidrotermal) sangat dipengaruhi oleh jenis dan jumlah bahan yang berikatan dengan protein kulit (Covington, 1994 cit. Kurniani, 2007). Suhu kerut adalah suhu dimana terjadi pengkerutan struktur kolagen. Pengkerutan terjadi karena adanya lipatan rantai polipeptida akibat putusnya kekuatan dari anyaman serabut oleh kondisi ekstrim seperti pemanasan pada suhu tinggi (Sarkar, 1995 cit. Kurniani, 2007).
Pada penelitian kami, puncak dari kurva DSC kulit mentah memiliki onset sebesar $57,37^{\circ} \mathrm{C}$ dan nilai entalpi 181,2658 J/g. Kestabilan kolagen terhadap suhu merupakan suatu adaptasi fisiologis ikan terhadap perubahan suhu lingkungannya (Ogawa et al., 2004). Menurut Jongjareonrak et al. (2004), kesetabilan kolagen kulit ikan dipengaruhi oleh komposisi 5 (lima) jenis asam amino utama (glisin, alanin, asam glutamat, prolin, dan hidroksiprolin).

Terlihat pada Gambar 1, suhu kerut teramati dari kulit yang diawetkan dengan penggaraman adalah $47,95^{\circ} \mathrm{C}$, nilai ini lebih rendah daripada suhu kerut kulit mentah yang sebesar $57,37^{\circ} \mathrm{C}$. Kulit hewan pada umumnya memiliki kandungan utama air sebesar $60-70 \%$ dan protein sebesar $30 \%$. Akibat kandungan air yang tinggi, maka degradasi kulit akan segera mulai berjalan sekitar 5-6 jam setelah hewan tersebut mati. Degradasi ini disebabkan khususnya oleh aktivitas dari mikroorganisme pada derma kulit. Natrium klorida yang digunakan pada penggaraman memiliki kemampuan dehidrasi dan bakteriostatik. Akan tetapi penggaraman yang dilakukan beberapa waktu setelah hewan tersebut mati memberikan kesempatan terjadinya degradasi pada matrik kolagen kulit.

Parameter yang sangat sensitif oleh terjadinya perubahan pada struktur kolagen adalah suhu kerut (Venkatachalam, 1977). Suhu kerut yang berubah menjadi lebih rendah mengindikasikan putusnya ikatan intermolekuler pada kolagen (Gudro, 2015). Penurunan suhu kerut sebesar $9,42^{\circ} \mathrm{C}$ menunjuk-

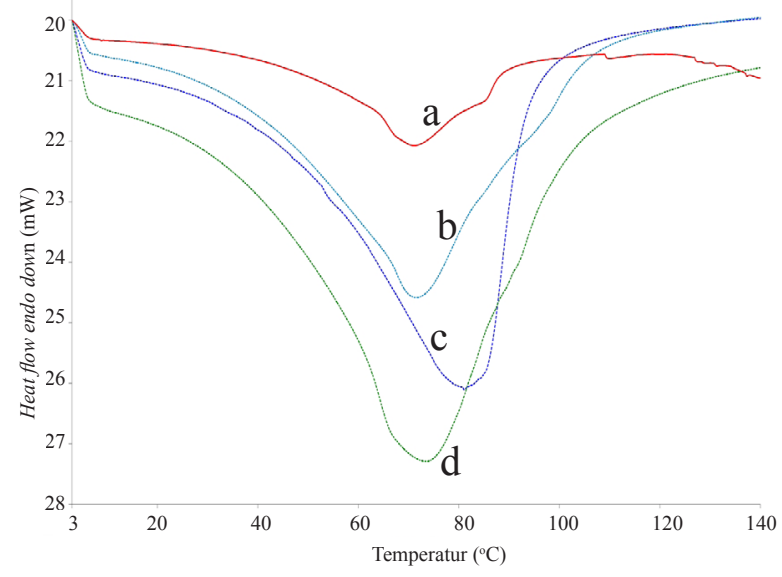

Gambar 1. Kurva DSC untuk tiap jenis sampel: (a) buntal mentah, (b) pengawetan dengan pengasaman, (c) pengawetan dengan formalin, (d) pengawetan dengan penggaraman. 
kan penurunan kualitas kulit akibat aktivitas mikroorganisme yang cukup intensif.

Hal yang berbeda terjadi pada nilai suhu kerut dari kulit ikan buntal yang diawetkan dengan formalin dimana nilai suhu kerutnya sebesar $63,64^{\circ} \mathrm{C}$. Suhu kerut tersebut lebih tinggi dibandingkan dengan suhu kerut kulit ikan mentah. Perbedaan ini dikarenakan penggunaan formalin selain dapat sebagai pengawet juga merupakan salah satu bahan kimia yang dapat digunakan sebagai bahan penyamak. Bahan penyamak akan membentuk ikatan silang dengan kolagen kulit. Keberadaan bahan penyamak akan meningkatkan kekuatan dari kulit dan mencegah kerusakan degradasi akibat bahan kimia, panas dan mikroorganisme (Krishnamoorthy et al., 2013). Pengawetan dengan formalin akan menaikkan suhu kerut kulit yang tidak tahan panas menjadi tahan terhadap suhu $70^{\circ} \mathrm{C}$ dan kulit tersamaknya kurang mempunyai afinitas terhadap beberapa zat dasar dari kulit samak krom atau nabati. Aldehid berikatan dengan gugus amino basa dari protein kuli dalam kondisi sedikit alkali, reaksi lebih cepat dan terjadi kondensasi dari beberpa molekul yang besar yang mana memberikan sifat lebih berisi dari kulit tersamaknya. O'Flaherty et al. (1958) menyatakan bahwa reaksi aldehida dan amina akan membentuk campuran metilalanin yang reaksinya berlangsung dalam suasana asam $(\mathrm{pH} 3,6)$ dikarenakan dalam pengikatannya terjadi perubahan suasana molekul yaitu terjadi pelepasan ion Hidrogen dari gugus $\mathrm{NH}_{3}^{+}$. dengan reaksi sebagai berikut:

$$
\begin{array}{r}
\mathrm{OPR}-\mathrm{NH}-\mathrm{CH}_{2} \mathrm{OH}+\mathrm{NH}_{2}-\mathrm{R}--> \\
\mathrm{R}-\mathrm{NH}-\mathrm{CH}_{2}-\mathrm{NH}_{2}-\mathrm{R}_{1}+\mathrm{H}_{2} \mathrm{O}
\end{array}
$$

Reaksi Formaldehyde berlangsung sehingga terjadi pembesaran molekul dan mengalami reaksi pemisahan air (kodensasi). Selanjutnya formaldehida akan menjadi jenuh sehingga berubah menjadi gas. Selanjutnya formaldehida dengan proteinprotein kulit secara keseluruhan berikatan dengan

Tabel 1. Suhu kerut pada kulit awetan.

\begin{tabular}{llc}
\hline No. & \multicolumn{1}{c}{ Sampel } & $\begin{array}{c}\text { Suhu } \\
\text { Kerut, }{ }^{\circ} \mathrm{C}\end{array}$ \\
\hline 1 & Kulit mentah (kontrol) & 57,37 \\
2 & Awetan dengan penggaraman & 47,95 \\
3 & Awetan dengan formalin & 63,64 \\
4 & Awetan dengan pengasaman & 49,31 \\
\hline
\end{tabular}

gugus amino utama dan gugus methylol mengalami reaksi menjadi jembatan metilin.

Nilai suhu kerut untuk kulit ikan buntal dengan pengawetan pengasaman sebesar $49,31^{\circ} \mathrm{C}$. Hasil ini lebih kecil daripada suhu kerut dari kulit ikan mentah. Nilai yang lebih kecil tersebut dikarenakan sebelum dilakukan pengasaman terdapat jeda waktu dengan saat ikan tersebut mati sehingga sudah mulai terjadi kerusakan pada matriks kolagen kulit. Pengasaman dimaksudkan untuk mencegah kerusakan lebih lanjut dari kulit, bukan untuk memperbaiki kondisi kulit. Pengawetan dengan cara pengasaman pada umumnya dilakukan dengan cara merendam kulit pada larutan asam. Pada prinsipnya bahan kimia yang bersifat asam dalam proses ini akan menyebabkan mikrobia tidak dapat tumbuh dan merusak kulit (PPP UGM, 2011).

Perbandingan pengujian suhu kerut dari sampel dapat dilihat pada Tabel 1. Suhu kerut teramati dari kulit yang diawetkan dengan penggaraman adalah $47,95^{\circ} \mathrm{C}$, nilai ini lebih rendah daripada suhu kerut kulit mentah yang sebesar $57,37^{\circ} \mathrm{C}$. Begitupula dengan suhu kerut dari kulit yang diawetkan dengan pengasaman sebesar $49,31^{\circ} \mathrm{C}$ yang juga lebih rendah dibandingkan kulit mentah. Sedangkan suhu kerut dari kulit ikan buntal dengan pengawetan formalin sebesar $63,64^{\circ} \mathrm{C}$ dan lebih tinggi daripada kulit ikan mentah. Suhu kerut erat kaitannya dengan kematangan kulit karena semakin banyak serabut kulit yang berikatan dengan bahan penyamak. Semakin matang kulit semakin tinggi suhu kerut sehingga kualitas kulit semakin baik karena ketahanan kulit terhadap panas (hydrothermal) semakin tinggi (Kurniani, 2007). Suhu kerut (shrinkage temperature) adalah temperatur produk yang cenderung mengakibatkan terjadinya penurunan daya ikat zat-zat yang terdapat didalam protein (Nayudama, 1978 cit. Ayufita, 2007). Fenomena tersebut sejalan dengan hasil pengujian kekuatan tarik dari kulit ikan buntal dengan pengawetan formalin yang lebih tinggi dibandingkan perlakuan pengawetan penggaraman dan pengasaman yaitu $147,39 \mathrm{~kg} / \mathrm{cm}^{2}$ (Wibowo et al., 2014) yang terlihat pada Tabel 2 .

Hasil pengawetan formaldehid yang memberikan nilai tertinggi di atas sesuai dengan pendapat Krishnamoorthy et al. (2013) bahwa keuntungan dari proses penyamakan adalah dapat memperbaiki kulit yang dihasilkan dengan cara mencegah pembusukan dan ketahanan terhadap bahan kimia, suhu, dan degradasi mikrobia.

Nilai $\Delta \mathrm{H}$ diperoleh dari panas endoterm di- 
Tabel 2. Nilai kuat tarik pada kulit awetan (Wibowo et al., 2014) .

\begin{tabular}{llc}
\hline No & \multicolumn{1}{c}{ Sampel } & $\begin{array}{c}\text { Kuat tarik, } \\
\mathrm{kg} / \mathrm{cm}^{2}\end{array}$ \\
\hline 1 & Kulit mentah (kontrol) & 180,80 \\
2 & Awetan dengan penggaraman & 146,38 \\
3 & Awetan dengan formalin & 105,70 \\
4 & Awetan dengan pengasaman & 147,39 \\
\hline
\end{tabular}

Tabel 3. $\Delta \mathrm{H}$ (dalam J/g) pada kulit awetan.

\begin{tabular}{cll}
\hline No & \multicolumn{1}{c}{ Sampel } & $\Delta \mathrm{H}, \mathrm{J} / \mathrm{g}$ \\
\hline 1 & Kulit mentah (kontrol) & 181,2658 \\
2 & Awetan dengan penggaraman & 379,2087 \\
3 & Awetan dengan formalin & 589,7657 \\
4 & Awetan dengan pengasaman & 498,0327 \\
\hline
\end{tabular}

bagi dengan jumlah berat sampel yang digunakan. Dari Tabel 2 terlihat bahwa nilai $\Delta H$ untuk masing-masing metode pengawetan berbanding linier dengan nilai suhu kerut. Kulit awetan dengan formalin memiliki nilai $\Delta \mathrm{H}$ tertinggi sebesar $589,7657 \mathrm{~J} / \mathrm{g}$ sebanding dengan nilai suhu kerut yang juga tertinggi dibandingkan dengan metode pengawetan lainnya. Menurut Badea et al. (2012) korelasi antara $\Delta \mathrm{H}$ dengan indikator kestabilan termal dari kulit, misal suhu kerut, tidak selalu berbanding linier.

\section{KESIMPULAN}

Suhu kerut kulit ikan buntal dengan pengawetan cara penggaraman dan pengasaman lebih rendah dibandingkan suhu kerut kulit ikan mentah, yang disebabkan adanya waktu jeda antara ikan mati dengan proses pengawetan sehingga matrik kolagen sudah mulai mengalami kerusakan oleh mikroorganisme. Sedangkan suhu kerut kulit ikan buntal dengan formalin lebih tinggi dibandingkan kulit ikan mentah dikarenakan fungsi formalin selain sebagai bahan pengawet juga dapat sebagai bahan penyamak sehingga memperbaiki kualitas kulit.

\section{UCAPAN TERIMA KASIH}

Ucapan terimakasih kepada Direktur Politeknik ATK Yogyakarta atas dukungan dalam penelitian ini.

\section{DAFTAR PUSTAKA}

Ayufita, D. P. (2002). Pengaruh lama perendaman dalam garam jenuh terhadap kualitas fisik kulit pari tersamak. Perikanan UGM, Yogyakarta.

Badea, E., Gatta, G. D., \& Usacheva, T. R. (2012). Effects of temperature and relative humidity on fibrillar collagen within parchment: A micro differential scanning calorimetry (micro DSC) study. Polymer Degradation and Stability, 97(2012), 346-353.

BBKKP (Balai Besar Penelitian dan Pengembangan Barang Kulit, Karet dan Plastik). (1991). Pengawetan kulit ikan laut secara digaram basah (wet salting). Yogyakarta, Indonesia: BBKKP.

Cucos, A., Budrugeac, P., \& Miu, L. (2014). DMA and DSC studies of accelerated aged parchment and vegetable-tanned leather samples. Thermochimica Acta, 583(2014), 86-93.

Ginting, A. B., Sutri, I., \& Jan, S. (2005). Penentuan parameter uji dan ketidakpastian pengukuran kapasitas panas pada differential scanning calorimeter. Jurnal Teknologi Bahan Nuklir, 1(1), 1-57.

Gudro, I. (2015). Raw hide preservation using vacuum under low temperature (Dissertation). Riga Technical University, Latvia.

Jeyapalina, S., Attenburrow, G. E., \& Covington, A. D. (2007). Dynamic mechanical thermal analysis (DMTA) of leather. Part 1: Effect of tanning agent on the glass transition temperature of collagen. Journal of the Society of Leather Technologists and Chemists, 91(6), 236-242.

Jongjareonrak, A., Benjakul, S., Visessanguan, W., Nagai, T., \& Tanaka, M. (2004). Isolation and characterisation of acid and pepsin-solubilised collagens from the skin of browns-tripe red snapper (Lutjanus vitta). Food Chemistry, 93(3), 475-484.

Kanagaraj, J., Sundar, V. J., Muralidharan, C., \& Sadulla, S. (2005). Alternatives to sodium chloride in prevention of skin protein degradation - A case study. Journal of Cleaner Production, 13(8), 825831.

Krishnamoorthy, G., Sadulla, S., Sehgal, P. K., \& Mandal, A. B. (2013). Greener approach to leather tanning process: d-Lysine aldehyde as novel tanning agent for chrome-free tanning. Journal of Cleaner Production, 42, 277-286.

Kurniani, A.G. (2002). Pengaruh metode pengawetan kulit mentah terhadap kualitas kulit pari tersamak. Perikanan UGM, Yogyakarta.

Martianingsih, N., \& Lukman A. (2010). Analisis sifat kimia, fisik, dan termal gelatin dari ekstraksi kulit ikan pari (Himantura gerrardi) melalui variasi jenis larutan asam. Dalam Prosiding Skripsi Semester Gasal 2009/2010. Surabaya, Indonesia: Institut Teknologi Sepuluh Nopember.

Nurjanah, S. (2008). Modifikasi pektin untuk aplikasi 
membran dengan asam dikarboksilat sebagai agen penaut silang (Skripsi). Institut Pertanian Bogor, Indonesia.

O'Flaherty, F., Roddy, W. T., \& Lollar, R. M. (1978). The Chemistry and Technology of Leather, Volume III, New York, USA: Reind Hold Publishing Corporotion.

Ogawa, M., Portier, R. J., Moody, M. W., Bell, J., Schexnayder, M. A., \& Losso, J. N. (2004). Biochemical properties of bone and scale collagens isolated from the subtropical fish black drum (Pogonia cromis) and sheepshead seabream (Archosargus probatocephalus). Food Chemistry, 88, 495-501.

PPP UGM (Pusat Pengembangan Pendidikan Universitas Gadjah Mada). (2011). Teknik penyamakan kulit ikan, laporan perkembangan hibah pembelajaran e-learning. Yogyakarta, Indonesia: PPP UGM.
Purnomo. E. (2009). Upholstery: Car automotifleather seat. Yogyakarta, Indonesia: Akademi Tekonologi Kulit.

Venkatachalam, P. S. (1977). Short-term preservation of hide with neem oil, Journal of the Society of Leather Technologists and Chemists, 61(1), 24.

Wibowo, R. L. M. S., Ari, N., Rofiatun, R., \& Ardiyansyah, P. (2014). Utilization of waste from puffer fish skin as alternative raw materials for leather tanning. In The $5^{\text {th }}$ International Conference on Sustainable Future for Human Security (SUSTAIN). Bali, Indonesia: Sustain.

Weber, M., \& de Beaufort, L. F. (1962). The fishes of the Indo-Australian archipelago. XI. Scleroparei, Hypostomides, Pediculati, Plec-tognathi, Opisthomi, Discoce-phali, Xenopterygii. New Delhi, India: A. J. Reprints Agency. 